\title{
PENGARUH VARIASI ARUS PENGELASAN SMAW TERHADAP KEKERASAN LOGAM INDUK DAN LOGAM LAS
}

1) Jurusan Perawatan dan Perbaikan Mesin,Politeknik Negeri Ketapang,Jl Rangga Sentap Dalong

Ketapang,Kalimantan Barat

Corresponding email $\left.{ }^{1 *}\right)$ : helanianto@yahoo.com

Received: 04-11-2020 Accepted: $14-12-2020$ Published: 28-12-2020

C)2020 Politala Press. All Rights Reserved.

\author{
Helanianto $^{\left.1^{*}\right)}$, Epriyandi ${ }^{1)}$, Hairian Rahmadi ${ }^{1)}$
}

Abstrak. Konstruksi komponen bangunan baik statik, dinamik, didukung elemen sambungan. Elemen sambungan menghubungkan antar struktur. Pengelasan merupakan metode penyambungan logam yang memanfaatkan penetrasi panas yang dihasilkan. Problem pemilihan jenis kuat arus menentukan besaran heat input yang dibutuhkan dalam pencairan logam. Penelitian ini bertujuan mempresentasikan trend kekerasan bagian sambungan terhadap perubahan kuat arus, oleh faktor kekerasan yang diakibatkan temperatur pengelasan. Metode yang digunakan adalah eksperimen, pengelasan SMAW dan pengujian kekerasan pada HAZ dan weld metal menggunakan alat uji hardness tester Rockwell type HRD-150, memperlihatkan bahwa kekerasan rata-rata raw material baja ST 37 yangdiperoleh dari hasil pengujian yakni 48,6 HRB. Nilai kekerasan pada logam las untuk proses pengelasan 70 Ampere, 90 Ampere dan 110 Ampere lebih rendah dibandingkan dengan nilai kekerasan row material, terjadi peningkatan nilai kekerasan HAZ pada semua spesimen untuk proses pengelasan 110 Ampere dengan nilai kekerasan 50,2 HRB atau sebesar 1,9\% dibandingkan dengan nilai kekerasan raw material.

Kata Kunci : pengelasan SMAW, kuat arus, kekerasan logam las dan HAZ

\begin{abstract}
The construction of building components is either static, dynamic, supported by connection elements. Joint elements connect structures to one another. Welding is a method of joining metals that takes advantage of the penetration of heat generated. The problem of selecting the type of current determines the amount of heat input required in melting metals. This study aims to present the hardness trend of the joint part to changes in current strength, by the hardness factor caused by the welding temperature. The method used was the experimental method, the SMAW welding method and the hardness test on HAZ and weld metal with the HRD-150 type Rockwell hardness tester, showing that the average hardness of the ST 37 steel raw material obtained from the test results was $48.6 \mathrm{HRB}$. The hardness value of the weld metal for the welding process 70 Ampere, 90 Ampere and 110 Ampere is lower than the row material hardness value, there is an increase in the HAZ hardness value on all specimens for the 110 Ampere welding process with a hardness value of $50.2 \mathrm{HRB}$ or $1.9 \%$ compared to the raw material hardness value
\end{abstract}

Keywords : SMAW welding, current strength, weld metal hardness and HAZ

To cite this article at https://doi.org/10.34128/je.v7i2.148

\section{Pendahuluan}

Konstruksi merupakan komponen penting dalam suatu bangunan baik statik maupun diynamik. Dimana konstruksi yang baik salah satunya didukung oleh elemen sambung yang mumpuni, efisien menurut kaidahkaidah teknik. Elemen sambung ini ada bermacam jenis, namun demikian fungsinya sama untuk menghubungkan struktur yang satu dengan yang lainnya. Salah satu jenis sambungan yang berkembang hingga 
saat ini yakni pengelasan, yang merupakan suatu metode penyambungan logam yang memanfaatkan penetrasi panas atau kalor yang dihasilkan.

Untuk memproduksi suatu barang atau kontruksi, logam-logam tersebut diberikan perlakuan atau teknik khusus. Salah satunya yaitu penyambungan besi yang disebut pengelasan. Pengelasan adalah suatu proses penyambungan logam menjadi satu akibat panas dengan atau tanpa pengaruh tekanan, atau dapat juga didefinisikan sebagai ikatan metalurgi yang ditimbulkan oleh gaya tarik menarik antara atom. Secara umum pengelasan yaitu teknik penyambungan atau penyatuan dari beberapa batang logam dengan memanfaatkan energi panas. Penyambungan dua buah logam menjadi satu dilakukan dengan cara pemanasan atau pelumeran, dimana kedua ujung logam yang akan disambung dibuat lumer atau dilelehkan dengan busur nyala atau panas yang didapat dari busur nyala listrik (gas pembakar) sehingga kedua ujung atau bidang logam menjadi bidang masa yang kuat dan tidak mudah dipisahkan. Terdapat dua jenis pengelasan yang populer di Indonesia, yaitu pengelasan dengan menggunakan busur nyala listrik/Shield metal arc welding (SMAW) dan las karbit/Oxy acetylene welding $(O A W)$.

Pemilihan parameter arus las yang tepat berpengaruh terhadap kekuatan dan perubahan sifat mekanis suatu logam. Arus yang digunakan terlalu rendah akan menyebabkan sukarnya penyalaan busur listrik, serta busur listrik yang terjadi tidak stabil. Panas yang terjadi tidak cukup untuk melelehkan elektroda dan bahan dasar sehingga hasilnya rigi-rigi las dan tidak rata serta penembusan kurang dalam. Sebaliknya bila arus terlalu tinggi maka elektroda akan mencair terlalu cepat dan akan menghasilkan permukaan las yang lebih lebar dan penembusan yang dalam.

Beberapa penelitian yang telah melakukan pendekatan dengan permasalahan tersebut diatas diantaranya; Dengan menggunakan metode teknik Neutron Diffraction $(N D)$ diperoleh hasil penelitian bahwa heat input yang sangat tinggi akan memperlambat laju pendinginan..Dengan menggunakan metode Eksperimen Faktorial diperoleh hasil penelitian: besar arus dan kecepatan volume aliran gas pelindung pada las SMAW memberikan pengaruh terhadap ketangguhan HAZ.[1] dan juga pengelasan dengan menggunakan pendinginan dengan metode SMAW pada kekerasan baja karbon ST 37 dengan media serbuk semen abu abu pada beban Rockwell $100 \mathrm{kgf} .[2]$

Berkaitan dengan hal-hal yang telah disampaikan diatas, faktor perubahan kuat arus menentukan heat input yang diterima logam sewaktu proses pengelasan terjadi. Dan seberapa besar dampak perubahan tersébut menjadi hal yang perlu untuk diketahui sebagai rambu-rambu dalam metode pengelasan. Pada nilai kekerasan yang paling tinggi terletak pada bagian spesimen yang paling dekat dengan semburan air pendingin dari nosel spesimenke 3 dengan perlakuan heat treatment pada temperatur $870^{\circ} \mathrm{C}$ dengan holding time 90 menit yang memiliki hasil kemapukerasan mendekati dengan standart ASTM metode uji A255.[3]

\section{Tinjauan Pustaka}

Definisi pengelasan menurut DIN (Deutsche Industrie Norman) adalah ikatan metalurgi pada sambungan logam atau logam paduan yang dilaksanakan dalam keadaan lumer atau cair. Pengelasan adalah penyambungan setempat dari beberapa batang logam dengan menggunakan energi panas. Pengelasan dapat diartikan dengan proses penyambungan dua buah logam sampai titik rekristalisasi logam, dengan atau tanpa menggunakan bahan tambah dan menggunakan energi panas sebagai pencair bahan yang dilas.

Proses pengelasan melibatkan pemanasan dan pendinginan, pada umumnya struktur mikro dari logam tergantung dari kecepatan pendinginannya dari temperatur terbentuknya fasa awal sampai ke temperatur kamar. Karena perubahan struktur ini dengan sendirinya sifat-sifat mekanik yang dimiliki juga berubah. Pada dasarnya daerah lasan terdiri dari tiga bagian yaitu logam las (weld metal), daerah terkena pengaruh panas yang sering disebut Heat Affected Zone (HAZ), dan logam induk yang tak terpengaruh panas. Daerah logam las adalah bagian dari logam yang pada waktu pengelasan mencair dan kemudian membeku. Daerah pengaruh panas atau HAZ adalah logam dasar yang bersebelahan dengan logam las yang selama proses pengelasan mengalami siklus termal pemanasan dan pendinginan cepat. Logam induk yang tak terpengaruh panas adalah bagian logam dasar dimana panas dan temperatur pengelasan tidak menyebabkan terjadinya perubahan-perubahan struktur dan sifat.

Pengaruh perlakuan temperatur pemanasan pada hasil pengelasan metode SMAW terhadap hardness logam induk dan logam las dengan kekerasan raw material specimen teruji sebesar $51.4 \mathrm{HRB}$. Pada pengujian titik menunjukkan heat treatment temperatur $900^{\circ} \mathrm{C}$ memiliki nilai kekerasan logam las $54.3 \mathrm{HRB}$ dan $\mathrm{HAZ} 52.7$ $\mathrm{HRB}$, pada temperatur heat treatment $800^{\circ} \mathrm{C}$ kekerasan logam las $52.6 \mathrm{HRB}$ dan HAZ $52 \mathrm{HRB}$, sedangkan pada heat treatment $700^{\circ} \mathrm{C}$ kekerasan logam las 48.2 HRB dan HAZ 51.4 HRB.[4]. Pada pengelasan dengan adanya perbedaan suhu dan temperatur yang terjadi akan mengalami defrkasi, the effect of heating temperature on the hardness, microstructure and $V$ - bending spring back result on commercial steel plate.[5]

Mengelas bukan hanya memanaskan dua bagian benda sampai mencair dan membiarkan membeku kembali, tetapi membuat lasan yang utuh dengan cara memberikan bahan tambah atau elektroda pada waktu dipanaskan sehingga logam mempunyai kekuatan seperti yang dikehendaki. Kekuatan sambungan las dipengaruhi beberapa faktor antara lain prosedur pengelasan, bahan yang akan dilas, elektroda dan kampuh yang digunakan. 
Pengelasan busur listrik atau Shield Metal Arc Welding (SMAW) adalah proses pengelasan yang menggunakan panas untuk mencairkan material dasar atau logam induk dan elektroda (bahan pengisi). Panas tersebut dihasilkan oleh lompatan ion listrik yang terjadi antara katoda dan anoda (ujung elektroda dan permukaan plat yang akan dilas). Panas yang dihasilkan dari lompatan ion listrik ini besarnya dapat mencapai $4000^{\circ} \mathrm{C}-4500^{\circ} \mathrm{C}$. Karena panas dari busur listrik maka logam induk dan ujung elektroda mencair dan membeku bersama.

Proses terjadinya pengelasan ini karena adanya kontak antara ujung elektroda dan material dasar sehingga terjadi hubungan pendek, saat hubungan pendek tersebut terjadi, elektroda harus ditarik membentuk sudut sehingga terbentuk busur listrik yaitu lompatan ion yang menimbulkan panas.

Arus pengelasan sendiri adalah aliran pembawa muatan listrik dari mesin las yang digunakan untuk menyambung dua logam dengan mengalirkan panas ke logam pengisi atau elektroda. Besarnya arus pengelasan yang diperlukan tergantung pada diameter elektroda, tebal bahan yang dilas, jenis elektroda yang digunakan, dan posisi pengelasan. Pengujian tarik dan impak pada pengerjaan pengelasan SMAW dengan mesin genset menggubakan diameter elektroda yang berbeda dengan didapatkan nilai nilai tegangan tarik,tegangan luluh,modulus elsatisitas serta nilai regangan lebih baik menggunakan elektroda 3,2 mm pada masing - masing ketebalan plat.[6]

Arus las merupakan parameter las yang langsung mempengaruhi penembusan dan kecepatan pencairan logam induk. Semalkin tinggi arus las makin dalam penembusan dan makin cepat pencairan logamnya. Besar arus pada pengelasan mempengaruhi hasil las bila arus terlalu rendah maka perpindahan cairan dari ujung elektroda yang digunakan sangat sulit dan busur listrik yang terjadi menjadi tidak stabil. Panas yang terjadi tidak cukup untuk melelehkan logam dasar, sehingga menghasilkan bentuk rigirigi las yang kecil dan tidak rata serta penembusan kurang dalam. Jika arus terlalu besar, maka akan menghasilkan manik melebar, butiran percikan kecil, serta penetrasi dalam. Seperti pada Gambar 1 berikut.

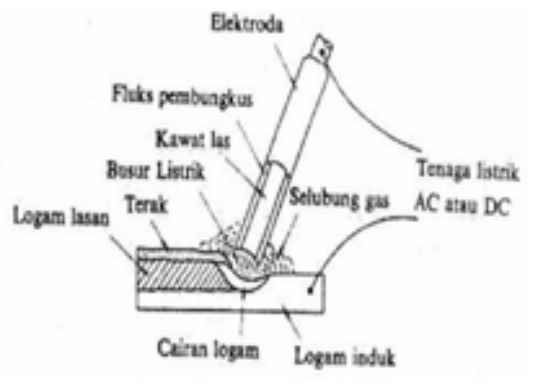

Gambar 1. Las Busur Dengan Elektroda Terbungkus

Adapun hal-hal yang perlu diperhatikan dalam pengelasan adalah sebagai berikut:

\section{Mesin Las}

a. Mesin las adalah bagian terpenting dari peralatan las. Mesin ini harus dapat memberi jenis tenaga listrik yang diperlukan dan tegangan yang cukup untuk terus melangsungkan suatu lengkung listrik las. Mesin las terdiri dari dua macam yakni mesin las arus bolak balik (mesin las AC) dan mesin las arus searah (mesin las DC). Pada mesin las AC terdapat transformator atau trafo yang berfungsi untuk menaikan atau menurunkan tegangan. Kebanyakan trafo yang digunakan pada peralatan las yaitu jenis trafo step-down, yakni untuk menurunkan tegangan. Sedangkan pada mesin las DC terdapat receifer atau penyearah arus yang berfungsi untuk mengubah arus bolak balik (AC) menjadi arus searah (DC).

b. Keuntungan dari penggunaan mesin las AC adalah perlengkapan dan perawatan lebih murah, kabel massa dan kabel elektroda dapat ditukar, tetapi tidak mempengaruhi hasil las, serta busur nyala kecil sehingga mengurangi timbulnya keropos pada rigi-rigi las. Keuntungan dari penggunaan mesin las DC yaitu busur nyala listrik yang dihasilkan stabil, dapat digunakan pada semua jenis

\section{Kampuh Las}

a. Kampuh las atau alur las merupakan bagian pada pengelasan yang nantinya akan diisi oleh logam las yang berasal dari kawat las atau logam pengisi. Berdasarkan banyaknya logam las yang mengisi kampuh, lasan dapat dibagi menjadi dua bagian, yaitu logam las mengisi seluruh bagian kampuh (penetrasi penuh) disebut dengan groove weld dan logam las tidak mengisi seluruh bagian kampuh (lasan penetrasi sebagian) maka jenis lasan ini dikenal sebagai fillet weld.

b. Sambungan las dalam kontruksi baja pada dasarnya dibagi dalam sambungan tumpul, sambungan $\mathrm{T}$, sambungan sudut dan sambungan tumpang. Pada gambar 2 berikut ini menunjukan jenis-jenis sambungan las. 


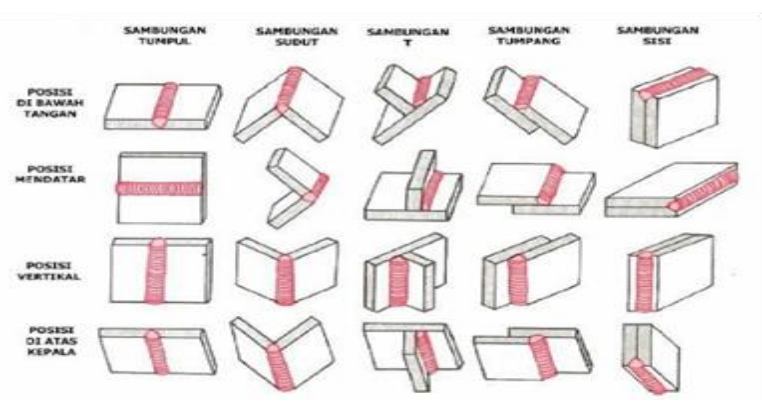

Gambar 2 Jenis-Jenis Sambungan Dan Posisi Pengelasan

\section{Elektroda}

a. Bagian yang sangat penting dalam las busur listrik, adalah elektroda las. Selama proses pengelasan elektroda akan meleleh dan akhirnya habis. Jenis elektroda yang digunakan akan sangat menentukan hasil pengelasan, sehingga sangat penting untuk mengetahui jenis dan sifat-sifat dari masing-masing elektroda sebagai dasar pemilihan elektroda yang tepat. Macam dan jenis elektroda sangat banyak. Berdasarkan selaput pelindungnya dibedakan menjadi dua macam, yaitu elektroda polos dan elektroda berselaput.

b. Elektroda berselaput terdiri dari bagian inti dan zat pelindung atau fluks. Pelapisan fluks pada bagian inti dapat dilakukan dengan cara destrusi, semprot atau celup. Selaput yang ada pada elektroda jika dibakar akan mengahsilkan gas CO2 yang berfungsi untuk melindungi cairan las, busur listrik dan sebagian benda kerja dari udara luar. Udara luar mengandung gas oksigen, yang dapat mengakibatkan bahan las mengalami oksidasi, sehingga dapat mempengaruhi sifat mekanis dari logam yang dilas. Oleh karena itu, elektroda berselaput yang digunakan untuk pengelasan benda-benda yang butuh kekuatan mekanis, misalnya tangki, konstruksi jembatan, dan konstruksi

\section{Posisi Pengelasan}

Dalam praktek pengelasan terdapat empat macam posisi mengelas, yaitu:

a. Posisi di bawah tangan (Down Hand Position)

Posisi di bawah tangan yaitu suatu cara pengelasan yang dilakukan pada permukaan rata/datar dan dilakukan di bawah tangan. Kemiringan elektroda las sekitar $10^{\circ}-20^{\circ}$ terhadap garis vertikal dan $70^{\circ}-80^{\circ}$ terhadap benda kerja.

b. Posisi tegak (Vertical Position)

c. Mengelas posisi tegak adalah apabila dilakukan arah pengelasannya keatas atau kebawah. Pengelasan ini termasuk pengelasan yang paling sulit karena bahan cair yang mengalir atau menumpuk di arah bawah dapat diperkecil dengan kemiringan elektroda sekitar $10^{\circ}-15^{\circ}$ terhadap garis vertikal dan $70^{\circ}-85^{\circ}$ terhadap benda kerja.

d. Posisi datar (Horizontal Position)

e. Mengelas dengan horizontal biasa disebut juga mengelas merata dimana kedudukan benda kerja dibuat tegak dan arah elektroda mengikuti horizontal. Sewaktu mengelas elektroda dibuat miring sekitar $5^{\circ}-10^{\circ}$ terhadap garis vertikal dan $70^{\circ}-80^{\circ} \mathrm{ke}$ arah benda kerja.

f. Posisi di atas kepala (Over Head Position)

g. Posisi pengelasan ini sangat sukar dan berbahaya karena bahan cair banyak berjatuhan dapat mengenai juru las, oleh karena itu diperlukan perlengkapan yang serba lengkap. Mengelas dengan posisi ini benda kerja terletak pada bagian atas juru las dan kedudukan elektroda sekitar $5^{\circ}-20^{\circ}$ terhadap garis vertikal dan $75^{\circ}-85^{\circ}$ terhadap benda kerja.Untuk lebih jelasnya posisi pengelasan dapat dilihat pada Gambar 3 berikut ini.
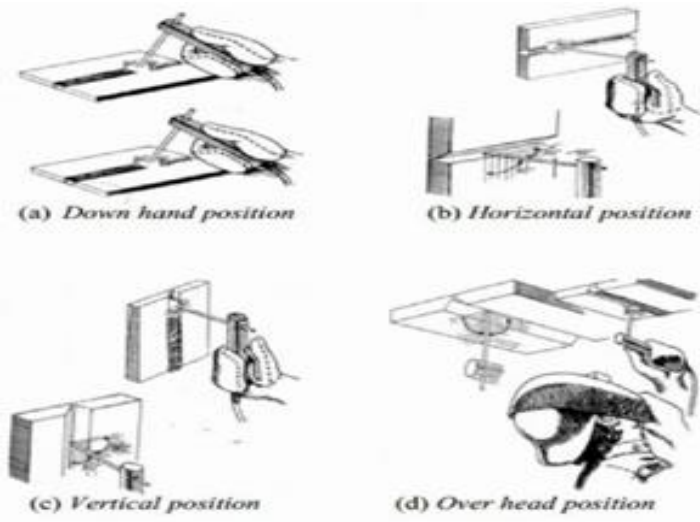

Gambar 3. Posisi Pengelasan 


\section{Arus Pengelasan}

Arus pengelasan adalah aliran pembawa muatan listrik dari mesin las yang digunakan untuk menyambung dua logam dengan mengalirkan panas ke logam pengisi atau elektroda. Besarnya arus pengelasan yang diperlukan tergantung pada diameter elektroda, tebal bahan yang dilas, jenis elektroda yang digunakan, dan posisi pengelasan. Arus las merupakan parameter las yang langsung mempengaruhi penembusan dan kecepatan pencairan logam induk. Semakin tinggi arus las makin dalam penembusan dan makin cepat pencairan logamnya. Besar arus pada pengelasan mempengaruhi hasil las bila arus terlalu rendah maka perpindahan cairan dari ujung elektroda yang digunakan sangat sulit dan busur listrik yang terjadi menjadi tidak stabil. Panas yang terjadi tidak cukup untuk melelehkan logam dasar, sehingga menghasilkan bentuk rigirigi las yang kecil dan tidak rata serta penembusan kurang dalam. Jika arus terlalu besar, maka akan menghasilkan manik melebar, butiran percikan kecil, serta penetrasi dalam.

\section{Pengaruh Kecepatan Pengelasan}

Kecepatan pengelasan sangat bergantung pada besar kuat arus yang digunakan, jenis elektroda, diameter inti elektroda, serta ketebalan bahan yang akan dilas. Dalam pengelasan, kecepatan yang tinggi dapat menyebabkan kurangnya penetrasi, berkurangnya kekuatan sambungan dan mengakibatkan masukan panas yang diterima persatuan panjang akan menjadi lebih kecil. Hal ini dapat berdampak pada pendinginan yang cepat sehingga dapat memperkeras daerah yang terpengaruh panas. Kecepatan las yang terlalu tinggi akan berpengaruh pada bentuk manik las yang menyempit dan penguatan manik yang rendah. Selain itu dapat merubah sifat mekanik daerah lasan yang berupa naiknya kekerasan hasil pengelasan.

\section{Heat Input}

Pencairan logam induk dan logam pengisi memerlukan energi yang cukup. Energi yang dihasilkan dalam operasi pengelasan dihasilkan dari bermacam-macam sumber tergantung pada proses pengelasannya. Pada pengelasan busur listrik, sumber energi berasal dari listrik yang diubah menjadi energi panas. Energi panas ini sebenarnya hasil kolaborasi dari arus las, tegangan las dan kecepatan pengelasan. Parameter ketiga yaitu kecepatan pengelasan ikut mempengaruhi energi pengelasan karena proses pemanasannya tidak diam akan tetapi bergerak dengan kecepatan tertentu. Hubungan antara ketiga parameter itu menghasilkan energi pengelasan yang sering disebut heat input. Persamaan dari heat input hasil dari penggabungan ketiga parameter dapat dituliskan sebagai berikut:

$$
\mathrm{HI}(\text { Heat Input })=\frac{\text { Tegangan Pengelasan }(\mathrm{E}) \mathrm{x} \text { Arus Pengelasan }(\mathrm{I})}{\text { Kecepatan Peneglasan }(\mathrm{V})}
$$

\section{Daerah Pengaruh Panas}

Logam akan mengalami pengaruh pemanasan akibat pengelasan dan mengalami perubahan struktur mikro disekitar daerah lasa. Bentuk struktur mikro bergantung pada temperatur tertinggi yang dicapai pada pengelasan, kecepatan pengelasan dan laju pendinginan daerah lasan. Daerah logam yang mengalami perubahan struktur mikro akibat mengalami pemanasan karena pengelasan disebut daerah pengaruh panas (DPP). Daerah las-lasan terdiri dari tiga bagian yaitu daerah logam las, daerah pengaruh panas atau heat affected zone (HAZ) dan logam induk yang tak terpengaruh panas.

a) Daerah logam las

Daerah logam las adalah bagian dari logam yang pada waktu pengelasan mencair dan kemudian membeku. Komposisi logam las terdiri dari komponen logam induk dan bahan tambah dari elektroda. Karena logam las dalam proses pengelasan ini mencair kemudian membeku, maka kemungkinan besar terjadi pemisahan komponen yang menyebabkan terjadinya struktur yang tidak homogen sehingga kekerasan dari logam las akan berbeda dengan kekerasan raw material,penurunan kekerasan yang terjadi daerah logam las (weld metal) terjadi karena siklus pemanasan dan pendinginan yang lama. Ketika arus yang digunakan untuk mengelas kecil, kecepatan pengelasan lambat akibat proses mencairnya logam induk dan elektroda yang lama sehingga kecepatan pendinginan logam las juga lambat menyebabkan kekerasan logam menurun namun keuletannya meningkat.

b) Daerah pengaruh panas atau heat affected zone (HAZ)

HAZ adalah logam dasar yang bersebelahan langsung dengan logam las yang selama proses pengelasan mengalami siklus termal pemanasan dan pendinginan cepat sehingga daerah ini paling kritis dari pada sambungan las, logam HAZ akan terjadi peningkatan kekerasan akibat dari proses rekristalisasi

c) Logam induk

Logam induk adalah bagian logam dasar dimana panas dan suhu pengelasan tidak menyebabkan terjadinya perubahan-perubahan struktur dan sifat. Di samping ketiga pembagian utama tersebut masih ada satu daerah pengaruh panas, yang disebut batas las. Daerah pengaruh panas pada logam yang dilas dapat dilihat pada Gambar 4berikut. 

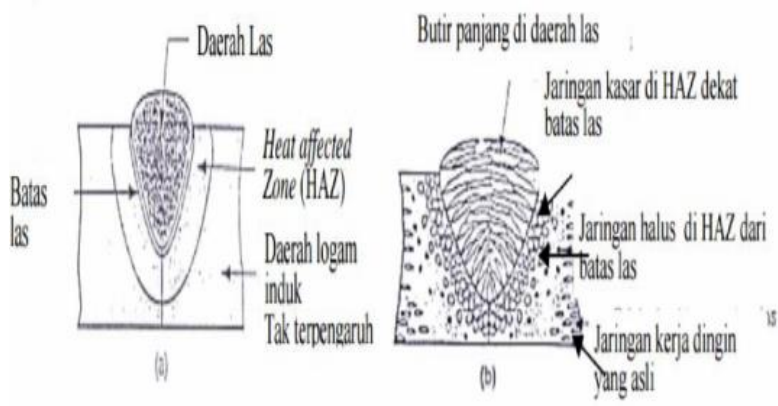

Gambar 4. Daerah Pengaruh Panas Las

Alat

Untuk membantu pelaksanaan eksperimen dibutuhkan beberapa alat penelitian diantaranya :

$>$ Alat potong logam

$>$ Mesin Las SMAW

$>$ Mesin milling/frais dan coolant

$>$ Mesin Rockwell (100kgf)

Bahan

$>\quad$ Plat Baja Karbon (ST-37) 3 mm

$>$ Elektroda

\section{Metodologi}

Perubahan kuat arus terhadap arus (Amper) mempengaruhi heat input kalor yang dihasilkan semakin tinggi ketika arus semakin besar, dan pencairan logam akan meningkat. Penelitian ini bertujuan membuktikan perubahan dengan karakter fisik sambungan (logam las dan HAZ) dan dampak terhadap kekuatan bagian sambungat yang diwakili uji kekerasan (hardness test) dengan metode Rockwell. Seperti pada Gambar 5 berikut.

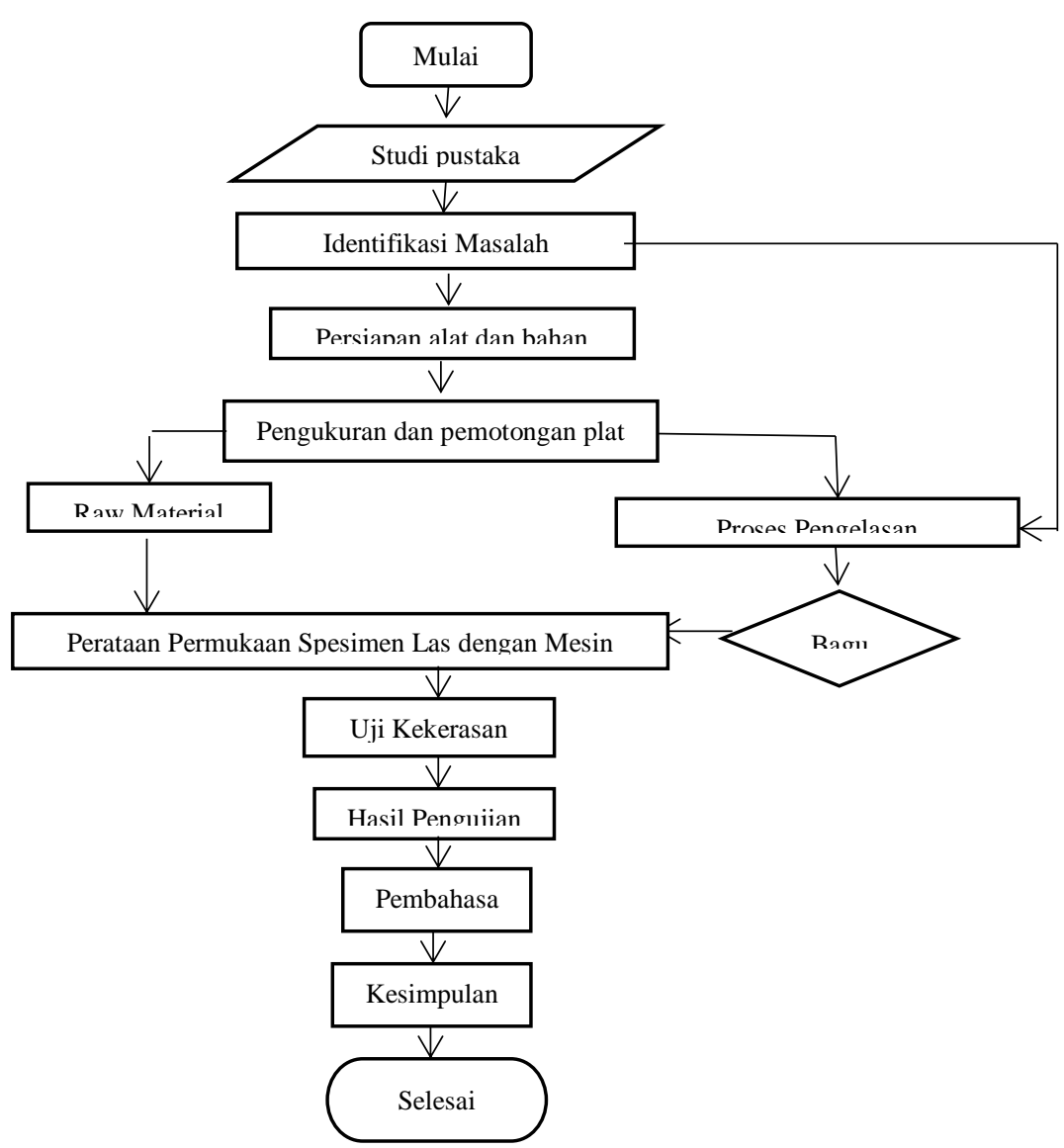

Gambar 5. Diagram Alir 


\section{Hasil dan Pembahasan}

\section{Proses Pemotongan Spesimen Uji}

Tahap awal dalam proses penelitian ini adalah mempersiapkan bahan spesimen uji. Material yang digunakandalam penelitian ini yaitu pelat baja karbon rendah dengan ukuran masing-masing spesimen yaitu 150 x 50 x 3 mm dengan jumlah 30 buah untuk menghasilkan 15 pasang sambungan las. Seperti yang diperlihatkan pada Gambar 6 berikut ini.

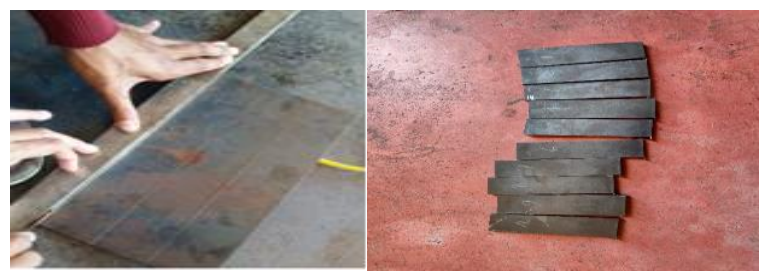

Gambar 6. Spesimen Uji

\section{Proses Pengelasan Spesimen}

Pengelasan dilakukan menggunakan kampuh tumpul terbuka, elektroda yang digunakn adalah RD 2.6 dengan diameter 2,6 mm, mesin las DC 220 volt. Proses pengelasan pada spesimendilakukan dengan posisi pengelasan vertikal dibawah tangan dengan pengaturan arus yang berbeda-beda yiatu 70 Ampere, 90 Ampere dan 110 Ampere.Spesimen uji yang di las sebanyak 15 buah yaitu 5 spesimen dengan pengaturan arus 70 ampere, 5 spesimen dengan pengaturan arus 90 ampere dan 5 spesimen dengan pengaturan arus 110 ampere. Proses pengelasan dan hasil las masing-masing spesimen dapat dilihat pada Gambar 7.

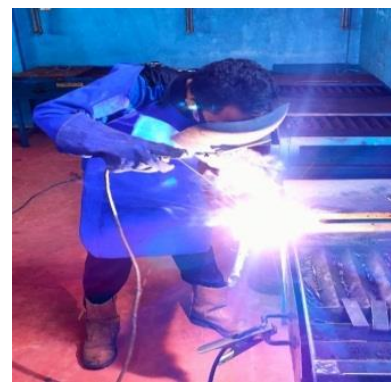

(a)

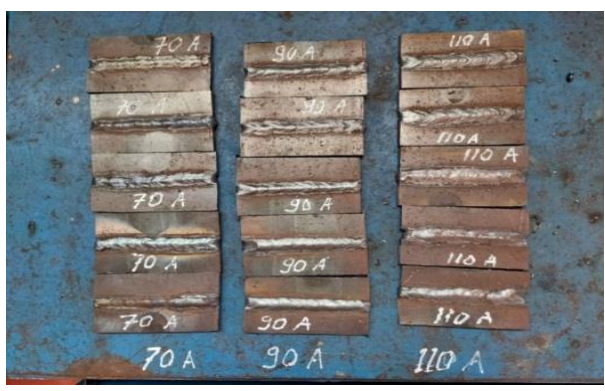

(b)

Gambar 7. (a) Proses Pengelasan Spesimen; (b) Hasil Pengelasan

\section{Pembuatan Spesimen}

Setelah dilakukan pengelasan, maka selanjutnya dilakukan pembuatan spesimen uji. Pembuatan spesimen uji menggunakan mesin frais.Plat yang telah dilas diratakan bagian permukaannya menggunakan mesin frais. Tujuan perataan menggunakan mesin frais adalah menjaga supaya struktur mikro dari logam las tidak berubah akibat terkena panas. Penggunaan mesin frais termasuk dalam pengerjaan dingin karena selama pengerjaan mata cutter dan tambahan cairan pendingin, sehingga data hasil pengujian yang diambil mengenai perbedaan arus pengelasan tetap valid. Gambar 8 memperlihatkan pembuatan spesimen uji menggunakan mesin frais.

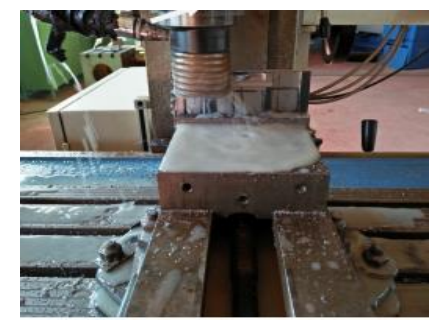

Gambar 8. Pembuatan Spesimen Uji dengan Mesin Frais

\section{Pengujian Kekerasan}

Pengujian kekerasan logam las menggunakan metode Rockwell bertujuanmenentukan kekerasan suatu material dalam bentuk daya tahan material terhadapindentor berupa bola baja ataupun kerucut intan yang ditekankan pada permukaanspesimen uji. Pada pengujian ini di gunakan Mesin Rockwell Motor Driven Hardness Tester Model HRD-150. Sebelum pengujian, pasang dudukan spesimen (anvil) dan juga indentor pada posisinya, pasang beban awal $10 \mathrm{kgf}$, kemudian sambungkan kabel ke sumber listrik. Tekan tombol power ( tombol berwarna hijau di sebelah kanan mesin), lalu atur waktu tahan selama 5 detik. 10 di 
bawah ini memperlihatkan anvil mesinuji kekerasan dan indentor berupa bola baja berukuran 1/16 inch yang digunakan dalam penelitian ini.
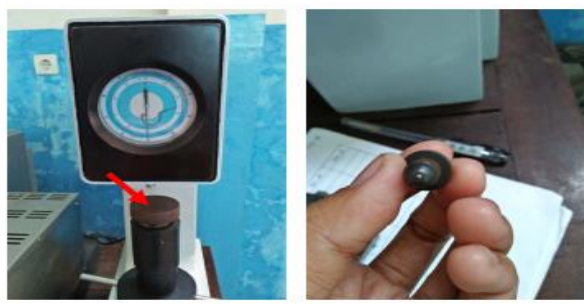

Gambar 9. Anvil dan Indentor Bola Baja

Pengujian kekerasan dilakukan pada daerah logam lasan dan HAZ dengan pengujian penekanan masing-masing lima titik. Kemudian angka hasil kekerasan diambil sebagai data penelitian. Proses pengujian dilakukan pada row material dan spesimen yang sudah dilakukan pengelasan. Setiap spesimen dilakukan pengujian sebanyak 5 titik uji.Untuk pengujian HAZ titik pengujian diambil dengan jarak $5 \mathrm{~mm}$ dari pusat logam las.

\section{Pengujian Raw Material}

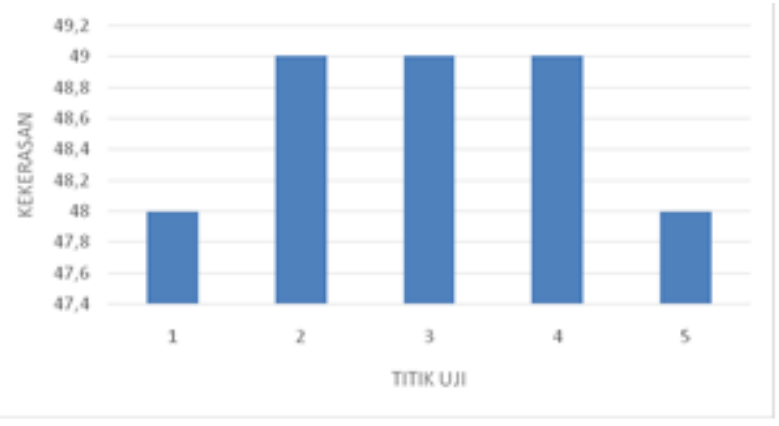

Gambar 10. Grafik Hasil Pengujian Raw Material

Dari hasil pengujian pada raw material yang pada Gambar 10, dapat diketahui bahwa kekerasan raw material sebelum dilakukan pengelasan yaitu $48 \mathrm{HRB}$ pada titik 1 dan tituk 5, sedangkan pada titik 2-4 nilai kekerasannya yaitu 49 HRB. Sehingga didapat nilai kekerasan rata-rata Raw Material sebelum dilakukan pengelasan yaitu 48,6 HRB.

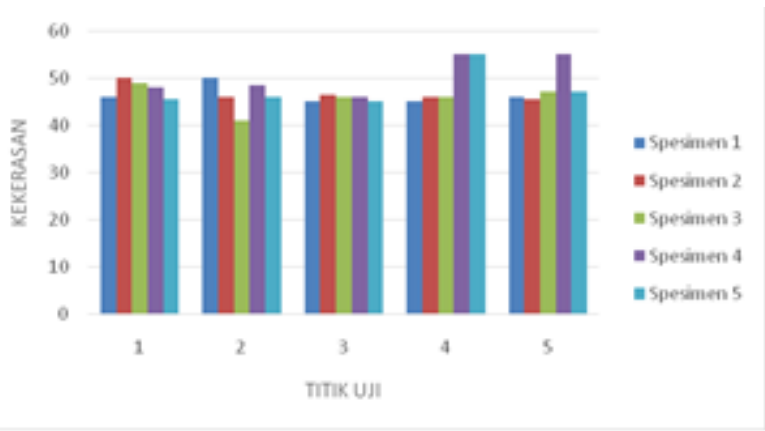

Gambar 11. Grafik Kekerasan Logam Las pada Pengelasan 70 Ampere

Gambar 11 merupakan hasil pengujian kekerasan logam las dengan proses pengelasan 70 Ampere. Dari gambar dapat dilihat bahwa nilai kekerasan terendah yaitu pada spesimen 3 dengan nilai kekerasan sebesar 41 HRB, sedangkan nilai kekerasan tertinggi sebesar 55 HRB pada spesimen 4 dan 5 . 


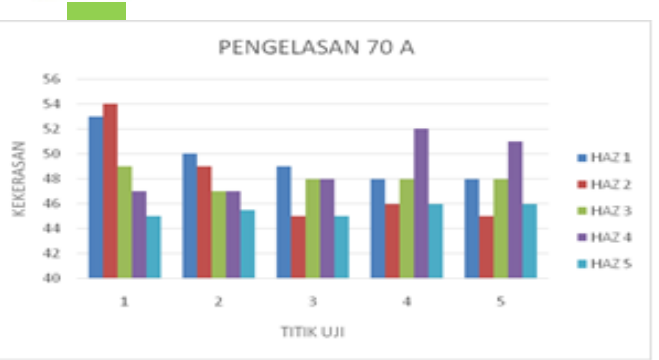

Gambar 12. Grafik Kekerasan HAZ pada Pengelasan 110 Ampere

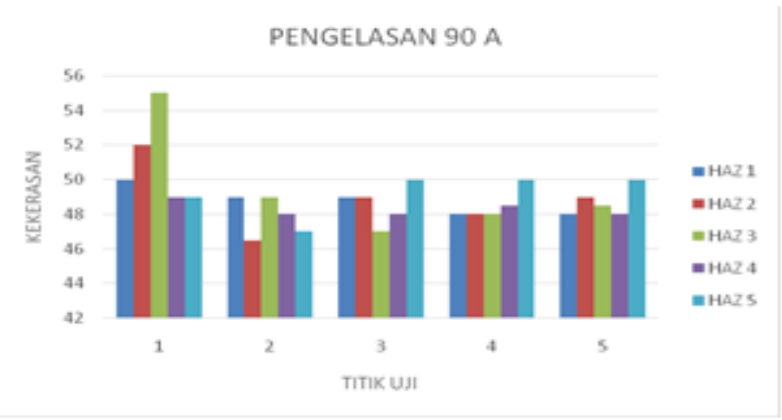

Gambar 14. Grafik Kekerasan Logam Las pada pengelasa 90 Ampere

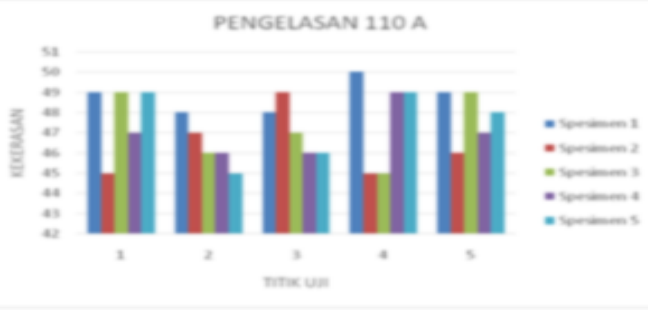

Gambar 13. Grafik Kekerasan Logam Las pada Pengelasan 70 Ampere

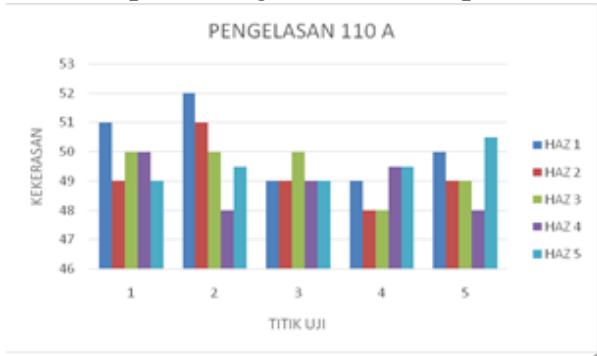

Gambar 15. Grafik Kekerasan HAZ pada Pengelasan 110 Ampere

Gambar 12,13,14,15, merupakan hasil pengujian kekerasan HAZ dengan proses pengelasan variasi Ampere. Dari gambar dapat dilihat bahwa nilai kekerasan terendah yaitu sebesar $45 \mathrm{HRB}$, sedangkan nilai kekerasan tertinggi sebesar $54 \mathrm{HRB}$. Untuk perbandingan nilai kekerasan logam las dan HAZ pada masingmasing spesimen dengan proses pengelasan 70 Ampere.

\section{Pengelasan 70, 90, dan 110 Ampere}

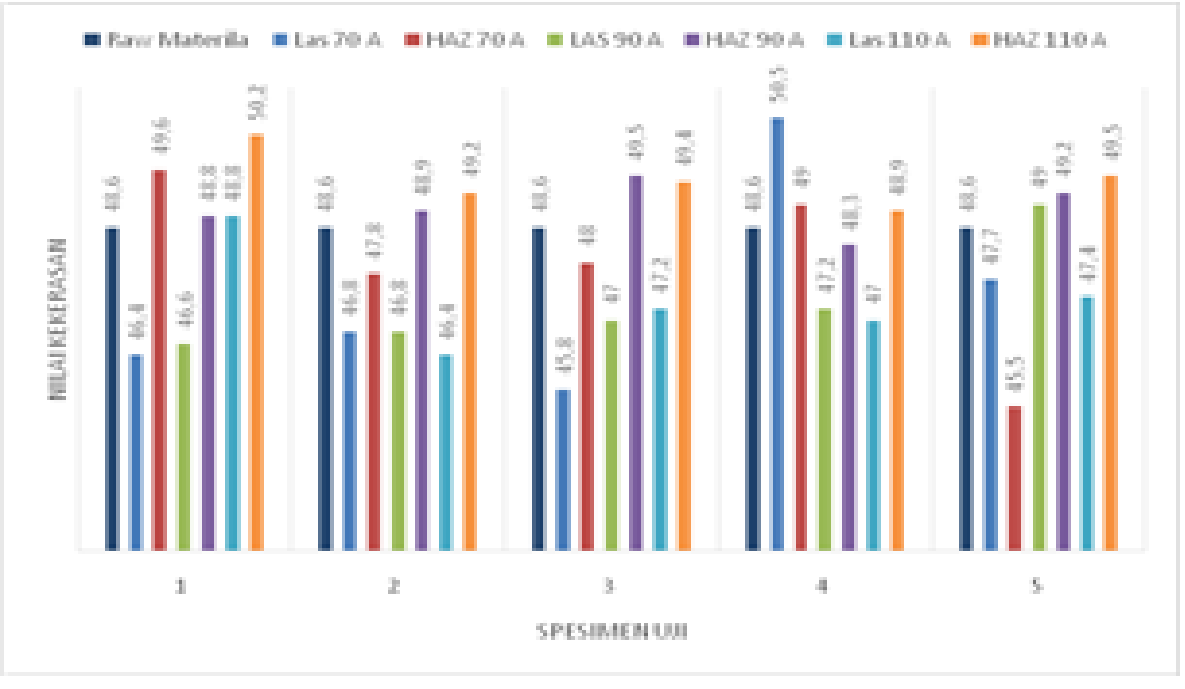

Gambar 16. Grafik Nilai Rata-Rata Hasil Pengujian Masing-Masing Spesimen

Perbandingan nilai kekerasan pada masing-masing spesimen uji dapat dilihat pada gambar 16. Dari gambar dapat dilihat bahwa nilai kekerasan logam las untk proses pengelasan 70 Ampere terjadi penurunan dari nilai kekerasan row material pada spesimen 1, 2, 3 dan 5, sedangkan pada spesimen 4 terjadi peningkatan. Begitu juga pada daerah HAZ, terjadi penurunan nilai kekerasan dibandingkan dengan nilai kekerasan row material yaitu pada spesimen 2,3 dan 5. Sedangkan pada spesimen 1 dan 4 terjadi peningkatan.

Pada proses pengelasan $90 \mathrm{~A}$, nilai kekerasan pada material las masih terjadi penurunan dibandingkan pada dengan nilai kekerasan row material, akan tetapi ada peningkatan dari nilai kekerasan dibandingkan dengan proses pengelasan 70 Ampere. Untuk nilai kekerasan HAZ terjadi peningkatan nilai kekerasan pada masingmasing spesimen dibandingkan dengan nilai kekerasan row material. Untuk proses pengelasan dengan arus 110 
Ampere, nilai kekerasan logam las masih dibawah nilai kekerasan row material, sedangkan pada HAZ nilai kekerasannya paling besar dibandingkan dengan nilai kekerasan spesimen lainnya.

\section{Kesimpulan}

Nilai kekerasan rata-rata raw material baja ST 37 yang diperoleh dari hasil pengujian yakni 48,6 HRB, nilai kekerasan pada logam las untuk proses pengelasan 70 Ampere, 90 Ampere dan 110 Ampere lebih rendah dibandingkan dengan nilai kekerasan raw material. Adanya peningkatan nilai kekerasan HAZ pada semua spesimen untuk proses pengelasan 110 Ampere dengan nilai kekerasan 50,2 HRB atau sebesar 1,9\% dibandingkan dengan nilai kekerasan raw material.

\section{Daftar Pustaka}

[1] I. N. Budiarsa, "Pengaruh besar arus pengelasan dan kecepatan volume alir gas pada proses las GMAW terhadap ketangguhan aluminium 5083," vol. 2, no. 2, p. 6, 2008.

[2] M. Anhar, "Pendinginan Pengelasan dengan Metode SMAW pada Kekerasan Baja Karbon ST37 dengan Media Serbuk Semen Abu-Abu pada Beban Rockwell 100 kgf," ROTASI, vol. 21, no. 3, p. 140, Aug. 2019, doi: 10.14710/rotasi.21.3.140-146.

[3] Y. - and Y. Chandra, "PENGARUH VARIASI HOLDING TIME TERHADAP KEMAMPUKERASAN BAJA MENGGUNAKAN ALAT UJI JOMINY," INOVTEK POLBENG, vol. 8, no. 2, p. 257, Dec. 2018, doi: 10.35314/ip.v8i2.769.

[4] H. Helanianto, "PENGARUH PERLAKUAN TEMPERATUR PEMANASAN PADA HASIL PENGELASAN METODE SMAW TERHADAP HARDNESS LOGAM INDUK DAN LOGAM LAS," J. Sist. Tek. Ind., vol. 19, no. 1, pp. 30-33, Aug. 2018, doi: 10.32734/jsti.v19i1.363.

[5] A. Ruchiyat, M. Anhar, Y. Yusuf, and B. S. E. Polonia, "The Effect Of Heating Temperature On The Hardness, Microstructure And V-Bending Spring Back Results On Commercial Steel Plate," J. Appl. Eng. Technol. Sci. JAETS, vol. 1, no. 1, pp. 1-16, Nov. 2019, doi: 10.37385/jaets.v1i1.10.

[6] M. Z. Mawahib, S. Jokosisworo, and H. Yudo, "Pengujian Tarik Dan Impak Pada Pengerjaan PengelasanSMAW Dengan Mesin Genset Menggunakan Diameter Elektroda Yang Berbeda," Kapal J. Ilmu Pengetah. Dan Teknol. Kelaut., vol. 14, no. 1, pp. 26-32, Feb. 2017, doi: 10.14710/kpl.v14i1.15533. 